\title{
Effectiveness of Hysteroscopic Myomectomy Compared to Medical Management on Patients' Quality of Life: A Randomized Clinical Trial
}

\author{
Maria Tam $^{1}$ and Loudes Juarez ${ }^{1}$ \\ ${ }^{1}$ AMITA Health
}

March 1, 2022

\begin{abstract}
Objective: To evaluate the quality of life in patients treated for submucosal leiomyomas after hysteroscopy myomectomy compared to medical therapy Patients: Patients with symptomatic submucosal leiomyomas from 2014-2017. A total of 69 patients enrolled, with 47 completed. Interventions: Each patient was randomized to (1) oral contraceptive pills/progesterone releasing intrauterine device or (2) hysteroscopic myomectomy using a hysteroscopic tissue removal system. Each patient was to complete the Uterine Fibroid Symptom and Health-related Quality of Life (UFS-QOL) questionnaire at baseline, one month, three months, and greater than or equal to six months after treatment. Measurements and Main Results: Primary outcome was the health-related quality of life (HR-QOL), as reflected from UFS-QOL scores. Contrasts were constructed from a linear mixed-effects model to compare the two treatment groups for changes from baseline in UFS-QOL scores. UFS-QOL scores were similar at baseline between the two treatment groups. There was an overall improvement in all UFS-QOL scores within each group. Higher improvement scores were noted in the surgical group compared to the medical group for almost all UFSQOL scores. At [?]6 months, in comparison to the medically managed patients, the most considerable score improvements for the surgical group were reported in HR-QOL concern, activities, self-consciousness and symptom severity scores having mean change scores (95\% CIs) of $35.3(22.3$ - 48.2), 28.9 (16.3 - 41.5), 28.6 (15.0 - 42.1), and $32.2(21.5$ - 43.0), respectively. Conclusion: Patients with submucosal leiomyomas who received medical or surgical treatment reported similar improvement in overall health related quality of life scores.
\end{abstract}

\section{Title:}

Effectiveness of Hysteroscopic Myomectomy Compared to Medical Management on Patients' Quality of Life: A Randomized Clinical Trial

\section{Authors:}

1. Teresa Tam, MD, FACOG, FACS (Corresponding author)

Affiliations:

Amita Saint Francis Hospital

Department of Obstetrics and Gynecology

355 Ridge Ave. Evanston, IL 60202

All For Women Healthcare

2845 N. Sheridan Suite \#902 Chicago, IL 60657

E-mail: drtam@allforwomenhealthcare.com 
2. Lourdes Juarez, MD

Affiliation:

Amita Saint Joseph Hospital

Department of Obstetrics and Gynecology 2900 North Lakeshore Drive Chicago, Illinois 60657 E-mail: lourdes.juarez.md@gmail.com

Short Title: Hysteroscopic Myomectomy on Quality of Life

\section{Hosted file}

BJOG- QOL Abstract.docx available at https://authorea.com/users/462885/articles/558179effectiveness-of-hysteroscopic-myomectomy-compared-to-medical-management-on-patientsquality-of-life-a-randomized-clinical-trial

\section{Hosted file}

BJOG QOL Main manuscript.docx available at https://authorea.com/users/462885/articles/558179effectiveness-of-hysteroscopic-myomectomy-compared-to-medical-management-on-patientsquality-of-life-a-randomized-clinical-trial

\section{Hosted file}

BJOG-Table 1 Demographics of Study Participants.docx available at https://authorea.com/users/ 462885/articles/558179-effectiveness-of-hysteroscopic-myomectomy-compared-to-medicalmanagement-on-patients-quality-of-life-a-randomized-clinical-trial

\section{Hosted file}

BJOG-Table 2. UFS-QOL Scores at Baseline.docx available at https://authorea.com/users/ 462885/articles/558179-effectiveness-of-hysteroscopic-myomectomy-compared-to-medicalmanagement-on-patients-quality-of-life-a-randomized-clinical-trial

\section{Hosted file}

BJOG-Table 3. Comparison in UFS-QOL.docx available at https://authorea.com/users/ 462885/articles/558179-effectiveness-of-hysteroscopic-myomectomy-compared-to-medicalmanagement-on-patients-quality-of-life-a-randomized-clinical-trial 
Figure 1. Subject Disposition Flowchart

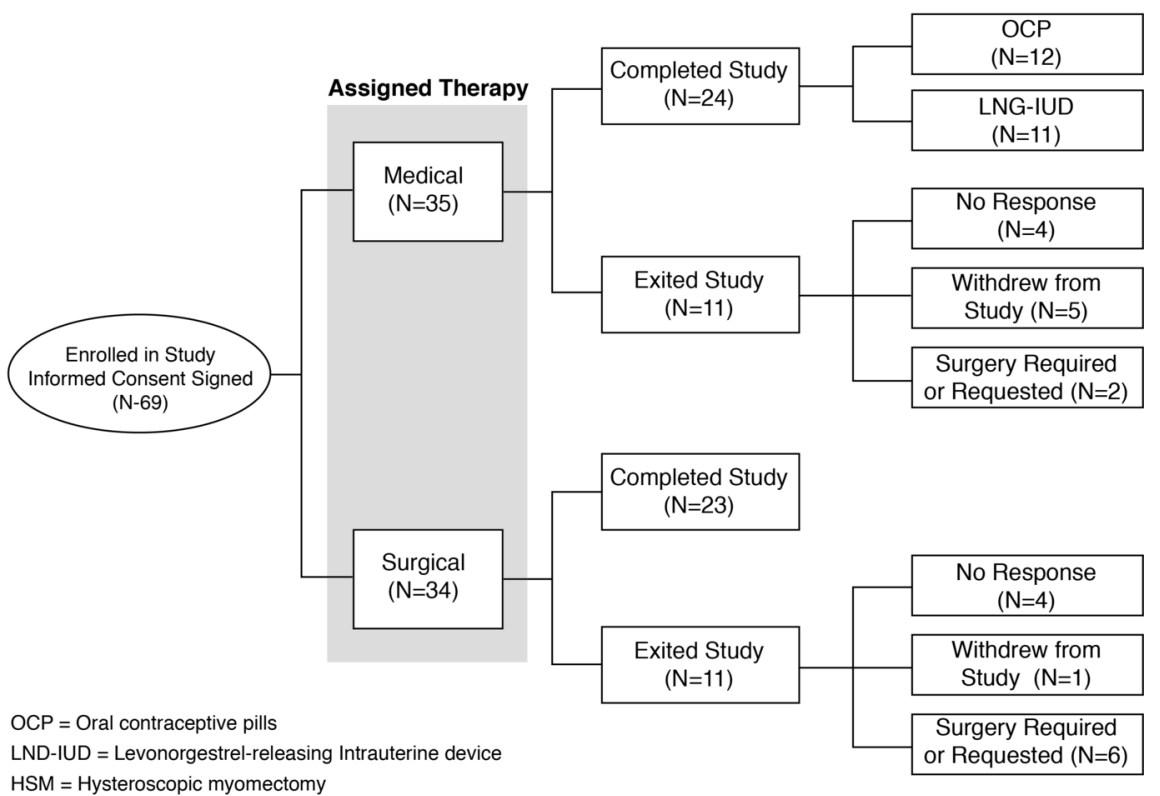

